\title{
Natural Occurrence of Alternaria Fungi and Associated Mycotoxins in Small-Grain Cereals from the Urals and West Siberia Regions of Russia
}

\author{
Aleksandra S. Orina ${ }^{1, * \mathbb{C}}$, Olga P. Gavrilova ${ }^{1}\left(\mathbb{D}\right.$, Nadezhda N. Gogina $^{2}$, Philipp B. Gannibal ${ }^{1}$ \\ and Tatiana Yu. Gagkaeva ${ }^{1}$ (D) \\ 1 Laboratory of Mycology and Phytopathology, All-Russian Institute of Plant Protection, \\ 196608 St. Petersburg, Russia; olgavrilova1@yandex.ru (O.P.G.); fgannibal@vizr.spb.ru (P.B.G.); \\ t.gagkaeva@yahoo.com (T.Y.G.) \\ 2 Laboratory of Biochemical Analysis, All-Russian Scientific Research and Technological Institute of Poultry, \\ 141311 Sergiev Posad, Russia; n.n.gogina@mail.ru \\ * Correspondence: orina-alex@yandex.ru; Tel.: +7-812-333-3764
}

Citation: Orina, A.S.; Gavrilova, O.P.; Gogina, N.N.; Gannibal, P.B.;

Gagkaeva, T.Y. Natural Occurrence of Alternaria Fungi and Associated Mycotoxins in Small-Grain Cereals from the Urals and West Siberia Regions of Russia. Toxins 2021, 13, 681. https://doi.org/10.3390/toxins 13100681

Received: 19 August 2021

Accepted: 23 September 2021

Published: 25 September 2021

Publisher's Note: MDPI stays neutral with regard to jurisdictional claims in published maps and institutional affiliations.

Copyright: (C) 2021 by the authors. Licensee MDPI, Basel, Switzerland. This article is an open access article distributed under the terms and conditions of the Creative Commons Attribution (CC BY) license (https:// creativecommons.org/licenses/by/ $4.0 /)$.

\begin{abstract}
Alternaria fungi dominate the grain microbiota in many regions of the world; therefore, the detection of species that are able to produce mycotoxins has received much attention. A total of 178 grain samples of wheat, barley and oat obtained from the Urals and West Siberia regions of Russia in 2017-2019 were included in the study. Grain contamination with Alternaria fungi belonging to sections Alternaria and Infectoriae was analysed using qPCR with specific primers. The occurrence of four mycotoxins produced by Alternaria, AOH, AME, TEN, and TeA, was defined by HPLC-MS/MS. Alternaria DNA was found in all analysed grain samples. The prevalence of DNA of Alternaria sect. Alternaria fungi (range $53 \times 10^{-4}-21,731 \times 10^{-4} \mathrm{pg} / \mathrm{ng}$ ) over the DNA of Alternaria sect. Infectoriae (range $11 \times 10^{-4}-4237 \times 10^{-4} \mathrm{pg} / \mathrm{ng}$ ) in the grain samples was revealed. Sixty-two percent of grain samples were contaminated by at least two Alternaria mycotoxins. The combination of TEN and TeA was found most often. Eight percent of grain samples were contaminated by all four mycotoxins, and only $3 \%$ of samples were free from the analysed secondary toxic metabolites. The amounts varied in a range of $2-53 \mu \mathrm{g} / \mathrm{kg}$ for $\mathrm{AOH}, 3-56 \mu \mathrm{g} / \mathrm{kg}$ for AME, 3-131 $\mu \mathrm{g} / \mathrm{kg}$ for TEN and 9-15,000 $\mu \mathrm{g} / \mathrm{kg}$ for TeA. To our knowledge, a new global maximum level of natural contamination of wheat grain with TeA was detected. A positive correlation between the amount of DNA from Alternaria sect. Alternaria and TeA was observed. The significant effects of cereal species and geographic origin of samples on the amounts of DNA and mycotoxins of Alternaria spp. in grain were revealed. Barley was the most heavily contaminated with fungi belonging to both sections. The content of $\mathrm{AOH}$ in oat grain was, on average, higher than that found in wheat and barley. The content of TEN in the grain of barley was lower than that in wheat and similar to that in oat. The content of TeA did not depend on the cereal crop. The effect of weather conditions (summer temperature and rainfall) on the final fungal and mycotoxin contamination of grain was discussed. The frequent co-occurrence of different Alternaria fungi and their mycotoxins in grain indicates the need for further studies investigating this issue.
\end{abstract}

Keywords: grain; Alternaria; fungi; DNA; mycotoxins; co-occurrence

Key Contribution: The ubiquitous presence of Alternaria spp. belonging to sections Alternaria and Infectoriae and their mycotoxins in the grain of wheat; barley and oats in the Urals and West Siberia was demonstrated.

\section{Introduction}

Alternaria Nees is a genus of ubiquitous fungi appearing on a wide range of substrates [1]. Most Alternaria species are pathogens responsible for plant diseases [2], but others can also live in plant tissue asymptomatically as endophytes $[3,4]$. Infection of 
crops with Alternaria spp. is common and can cause significant economic losses [5]. The contamination of crops with Alternaria fungi and the subsequent accumulation of their toxic metabolites in food and feed have been thoroughly investigated [6,7].

Many recent studies have demonstrated the predominance of Alternaria spp. in the mycobiota of cereal grains grown around the world [8-13]. Moreover, most of these Alternaria strains belong to A. section Alternaria Lawrence, Gannibal, Peever \& Pryor and A. sect. Infectoriae Woudenb. \& Crous [10,14], whereas species from sections Pseudoalternaria D.P. Lawr., Rotondo \& Gannibal and Panax D.P. Lawr., Gannibal, Peever \& B.M. Pryor appear sporadically [15-17].

In addition to the classic mycological methods for determining grain contamination with fungi, molecular approaches based on polymerase chain reaction (PCR), including realtime PCR, are currently actively used. The method allows quick and objective assessment of the quantitative presence of various fungal species in grain based on the content of their DNA, thereby eliminating errors at the taxonomic level $[8,18,19]$.

Alternaria mycotoxins are widely found in a variety of food and feed [20]. The number of mycotoxins produced by Alternaria fungi has reached at least 70 compounds [21]. The most common of them in grain are alternariol $(\mathrm{AOH})$, alternariol monomethyl ether (AME), tentoxin (TEN), and tenuazonic acid (TeA), which are often analysed and detected [14,22-26]. Presumably, $\mathrm{AOH}$ and AME have genotoxic, mutagenic and carcinogenic effects in humans and animals [20]. TeA is an inhibitor of protein synthesis and is a more toxic compound than $\mathrm{AOH}$ and AME [27]. TEN is relatively weakly toxic to mammals, but it is also a nonspecific phytotoxin and inhibits the development of chloroplasts, causing chlorosis of host plant tissues [27].

As a result of toxicological studies, it was proposed to introduce a restriction on the content of TeA at $500 \mu \mathrm{g} / \mathrm{kg}$ in infant food [28]. In June 2019, a draft EU Commission Recommendation on the monitoring of three Alternaria mycotoxins ( $\mathrm{AOH}, \mathrm{AME}, \mathrm{Te}$ ) in food was issued: benchmark values in cereal-based foods for infants and children were $5 \mu \mathrm{g} / \mathrm{kg}$ for $\mathrm{AOH}$ and AME and $500 \mu \mathrm{g} / \mathrm{kg}$ for TeA [29]. There is no state standard regulating the content of Alternaria mycotoxins in food and feed in Russia.

The monitoring of grain infection with Alternaria fungi is always relevant because these organisms are able to produce mycotoxins, which can negatively affect grain consumers [27,30]. The potential for the production of mycotoxins by Alternaria spp. strains may differ significantly and depends greatly on environmental conditions [30,31]. The Alternaria species belonging to various Alternaria sections differ significantly in their toxin-producing ability [30,32-34] and pose different risks when contaminating food.

In Russia, several studies of occurrence of Alternaria fungi and their mycotoxins in grain cultivated in different regions have been carried out $[10,14,35,36]$. Previously, mycotoxins produced by Alternaria fungi were detected in grain samples mostly obtained from the central and southern regions of the European part of Russia and from the Urals; at the same time, information on grain contamination with Alternaria mycotoxins in Siberia was fragmentary $[14,35,36]$. It was noted that grain samples from the main grain-producing regions of Russia, such as the Southern European and North Caucasus regions, are less contaminated with Alternaria mycotoxins than those from the Central European, Volga, Urals and Siberian regions [36].

The main grain crop cultivated in the Urals and West Siberia regions is spring wheat, which is grown on $\sim 60 \%$ of the total sown area of cereal crops in Russia. Oats $(\sim 50 \%)$ and barley $(\sim 24 \%)$ are also widely grown in these regions [37].

The aims of the present study were to determine the contamination of grain of spring wheat, barley and oat grown in the Urals and West Siberia regions of Russia in 2017-2019 by Alternaria fungi and their mycotoxins and to reveal the key factors affecting their distribution. 


\section{Results}

\subsection{The Approbation of the qPCR Protocol}

The parameters of the adapted qPCR for analysis of the DNA content of $A$. sect. Alternaria fungi were $99.0 \%$ efficient, $\mathrm{R}^{2}=0.999$, and a slope of -3.35 . The parameters of the adapted qPCR for analysis of the DNA content of $A$. sect. Infectoriae were $101.1 \%, \mathrm{R}^{2}=0.997$, and slope -3.30 . The level of specificity of the analysis is presented in Table 1 . The amplification of the target DNA was detected at $11.2 \pm 0.6$ cycles for primers AAF2/AAR3 and at $21.1 \pm 0.7$ cycles for primers AinfF3/AinfR4. Nonspecific DNA amplification was detected after 32 cycles for both primer sets.

Table 1. Specificity of qPCR for detection of Alternaria spp. DNA.

\begin{tabular}{cccc}
\hline \multirow{2}{*}{ Strain ID } & Fungi & \multicolumn{2}{c}{ Results of qPCR with Primer Pairs (Ct 1) $^{\text {1 }}$} \\
\cline { 2 - 4 } & & AAF2/AAR3 & AinfF3/AinfR4 \\
MFP556081 & A. tenuissima (sect. Alternaria) & 10.9 & 33.7 \\
MFP028011 & Alternaria sp. (sect. Alternaria) & 11.5 & 34.4 \\
MFP094121 & Alternaria sp. (sect. Pseudoalternaria) & 34.6 & 35.5 \\
MFP457051 & Alternaria sp. (sect. Pseudoalternaria) & 32.9 & 37.7 \\
MFP094331 & Alternaria sp. (sect. Infectoriae) & 34.1 & 20.8 \\
MFP778011 & Alternaria sp. (sect. Infectoriae) & 35.5 & 21.5 \\
MFG59013 & Bipolaris sorokiniana & n.d. & 34.5 \\
MFG232100 & Cladosporium sp. & n.d. & 35.4 \\
MFG60204 & Fusarium avenaceum & n.d. & n.d. \\
MFG102100 & F. culmorum & n.d. & n.d. \\
MFG11039 & F. sporotrichioides & n.d. & 38.8 \\
MFG14000 & Trichothecium roseum & n.d. & \\
\hline
\end{tabular}

${ }^{1} \mathrm{Ct}$-amplification cycle corresponding to the cross of fluorescence curve with the threshold; ${ }^{2}$ n.d.-absence of amplification products.

\subsection{Content of Alternaria DNA in the Grain Samples}

The qPCR results showed that all analysed grain samples were contaminated with DNA from both Alternaria sections. The amounts of $A$. sect. Alternaria DNA varied from $53 \times 10^{-4}$ to $21,731 \times 10^{-4} \mathrm{pg} / \mathrm{ng}$, while the amounts of $A$. sect. Infectoriae DNA were in the range of $11 \times 10^{-4}-4237 \times 10^{-4} \mathrm{pg} / \mathrm{ng}$ (Table 2).

Table 2. The content of Alternaria DNA in the grain samples of different cereals from the Urals and West Siberia.

\begin{tabular}{|c|c|c|c|c|}
\hline \multirow{2}{*}{ Cereal } & \multirow{2}{*}{ Region } & \multirow{2}{*}{$\begin{array}{c}\text { Crop Year (Number of } \\
\text { Samples) }\end{array}$} & \multicolumn{2}{|c|}{ The Range of Alternaria DNA Amounts $\times 10^{-4}, \mathrm{pg} / \mathrm{ng}$ of Total DNA } \\
\hline & & & A. sect. Alternaria & A. sect. Infectoriae \\
\hline \multirow{6}{*}{ wheat } & \multirow{3}{*}{ the Urals } & $2017(13)$ & $881-3079$ & 117-2388 \\
\hline & & $2018(23)$ & $736-4580$ & $36-1462$ \\
\hline & & $2019(10)$ & $1165-3826$ & $55-544$ \\
\hline & \multirow{3}{*}{ West Siberia } & $2017(26)$ & $1027-6442$ & $158-877$ \\
\hline & & $2018(21)$ & $1213-21,731$ & 91-1187 \\
\hline & & $2019(23)$ & $426-3851$ & $35-1204$ \\
\hline \multirow{5}{*}{ barley } & \multirow{2}{*}{ the Urals } & 2018 (15) & $497-5568$ & $26-3616$ \\
\hline & & $2019(8)$ & $361-7146$ & $43-1051$ \\
\hline & \multirow{3}{*}{ West Siberia } & $2017(2)$ & 12,$721 ; 9695$ & $4237 ; 2746$ \\
\hline & & 2018 (15) & $53-10,526$ & $252-1472$ \\
\hline & & $2019(9)$ & $820-4776$ & $103-535$ \\
\hline \multirow{4}{*}{ oat } & \multirow{2}{*}{ the Urals } & $2018(2)$ & $1093 ; 1452$ & $88 ; 326$ \\
\hline & & $2019(4)$ & $313-3323$ & $11-227$ \\
\hline & \multirow[b]{2}{*}{ West Siberia } & $2018(5)$ & $905-3472$ & $79-327$ \\
\hline & & 2019 (2) & $624 ; 526$ & $139 ; 91$ \\
\hline
\end{tabular}


Obviously, the amounts of DNA from Alternaria fungi belonging to sect. Alternaria were significantly more abundant in all analysed grain samples than in A. sect. Infectoriae. The differences in the average amounts reached 2.2-16.2 times. At the same time, a positive correlation $(\mathrm{r}=0.46, p<0.001)$ was found between the amounts of Alternaria fungi DNA from these two sections.

\subsection{Content of Alternaria Mycotoxins in the Grain Samples}

Five grain samples (four barley and one wheat) were free of Alternaria mycotoxins. Most grain samples (62\%) were contaminated with a combination of any two mycotoxins. However, $16 \%$ and $8 \%$ of grain samples were contaminated by three (mostly the combination of $\mathrm{AOH}+\mathrm{TEN}+\mathrm{TeA}$ ) and four mycotoxins, respectively.

Generally, mycotoxin $\mathrm{AOH}$ was found in $27 \%$ of grain samples, AME was detected in $12 \%$ of grain samples, and their content ranged from $2-53$ and $3-56 \mu \mathrm{g} / \mathrm{kg}$, respectively (Table 3). TEN turned out to be the most common Alternaria mycotoxin and was found in $90 \%$ of grain samples at levels of $3-131 \mu \mathrm{g} / \mathrm{kg}$. TeA was found in $85 \%$ of grain samples, and its content was $9-14,963 \mu \mathrm{g} / \mathrm{kg}$, which on average exceeded the content of other analysed Alternaria mycotoxins by 10-27 times. The proportion of grain samples containing TeA in amounts $>500 \mu \mathrm{g} / \mathrm{kg}$, which is higher than the future recommended limit [28], was $4 \%$ of all analysed samples. Most of them originated from West Siberia. The maximum contents of Alternaria mycotoxins were detected in the grain samples from West Siberia: $\mathrm{AOH}-\mathrm{oat}$, Novosibirsk oblast, 2019; AME—wheat, Krasnoyarsky Krai, 2017; TEN—wheat, Altai Krai, 2017; and TeA—wheat, Altai Krai, 2018.

Table 3. The content of mycotoxins produced by Alternaria fungi in the grain samples of different cereals from the Urals and West Siberia regions of Russia.

\begin{tabular}{|c|c|c|c|c|c|}
\hline \multirow[t]{2}{*}{ Region } & \multirow{2}{*}{$\begin{array}{c}\text { Year of Crop } \\
\text { (No. of Samples) }\end{array}$} & \multicolumn{4}{|c|}{$\begin{array}{l}\text { Number of Contaminated Samples/ } \\
\text { Range of Mycotoxin Amounts, } \mu \mathrm{g} / \mathrm{kg}\end{array}$} \\
\hline & & $\mathrm{AOH}$ & AME & TEN & $\mathrm{TeA}$ \\
\hline \multicolumn{6}{|c|}{ wheat } \\
\hline \multirow{3}{*}{ the Urals } & 2017 (13) & $3 / 2-4$ & nd/0 & $13 / 4-48$ & $13 / 15-226$ \\
\hline & 2018 (23) & $6 / 3-26$ & $3 / 5-5$ & $21 / 3-79$ & $16 / 35-454$ \\
\hline & 2019 (10) & $1 / 15$ & nd $1 / 0$ & 7/5-19 & 10/19-97 \\
\hline \multirow{3}{*}{ West Siberia } & $2017(26)$ & $13 / 2-44$ & $9 / 3-56$ & 26/9-131 & $26 / 17-545$ \\
\hline & $2018(21)$ & 7/3-14 & $2 / 3 ; 4$ & $20 / 4-83$ & $16 / 37-14,963$ \\
\hline & 2019 (23) & $6 / 7-17$ & $3 / 4-6$ & $17 / 3-36$ & 23/16-241 \\
\hline \multicolumn{6}{|c|}{ barley } \\
\hline \multirow{2}{*}{ the Urals } & 2018 (15) & $3 / 2-8$ & $1 / 3$ & $14 / 5-80$ & $13 / 15-593$ \\
\hline & $2019(8)$ & $1 / 3$ & $\mathrm{nd} / 0$ & 7/5-10 & $7 / 14-570$ \\
\hline \multirow{3}{*}{ West Siberia } & $2017(2)$ & $\mathrm{nd} / 0$ & $\mathrm{nd} / 0$ & $2 / 9 ; 12$ & $\mathrm{nd} / 0$ \\
\hline & 2018 (15) & $\mathrm{nd} / 0$ & $\mathrm{nd} / 0$ & $13 / 5-38$ & $7 / 30-349$ \\
\hline & $2019(9)$ & $2 / 4 ; 5$ & $\mathrm{nd} / 0$ & $7 / 3-6$ & 9/9-113 \\
\hline \multicolumn{6}{|c|}{ oat } \\
\hline \multirow{2}{*}{ the Urals } & $2018(2)$ & $1 / 19$ & $1 / 3$ & $2 / 16 ; 21$ & $2 / 65 ; 228$ \\
\hline & $2019(4)$ & $2 / 11 ; 13$ & $2 / 4 ; 11$ & 4/3-15 & 3/59-276 \\
\hline \multirow{2}{*}{ West Siberia } & $2018(5)$ & $1 / 4$ & $\mathrm{nd} / 0$ & $5 / 13-88$ & 5/164-405 \\
\hline & $2019(2)$ & $2 / 7 ; 53$ & $1 / 22$ & $2 / 15 ; 15$ & $2 / 280 ; 1579$ \\
\hline
\end{tabular}

${ }^{1}$ nd-none of the samples contained mycotoxin.

The combination of TEN and TeA was identified most often. The co-occurrence of $\mathrm{AOH}$ and AME was detected fairly rarely, and, as a rule, the AME content was lower than the $\mathrm{AOH}$ content. A significant positive correlation $(\mathrm{r}=0.66, p<0.001)$ between the 
contents of these two mycotoxins was revealed. As expected, a slight positive correlation between the contents of $\mathrm{AOH}$ and $\mathrm{TeA}$ was also detected $(\mathrm{r}=0.17, p<0.02)$.

A strong positive correlation between the content of $A$. sect. Alternaria DNA and TeA was revealed $(r=0.63, p<0.001)$, which allows us to assume that these fungi are the main producers of this mycotoxin in cereal grains in the observed territory. The connection between the amount of $A$. sect. Infectoriae DNA and TEN contents was revealed $(\mathrm{r}=+0.31$, $p=0.008$ ) when the grain samples from the Urals were analysed separately. No other significant correlations between the content of mycotoxins and their potential producers were established.

\subsection{Factors Affecting Grain Contamination}

The results of the statistical analysis revealing the impact of different factors on the final content of fungal DNA in grain samples are summarized in Table 4.

Table 4. The effect of different factors on the content of Alternaria DNA and mycotoxins in grain.

\begin{tabular}{|c|c|c|c|c|c|c|}
\hline \multirow[b]{2}{*}{ Factors } & \multicolumn{6}{|c|}{ Analysed Parameters } \\
\hline & $\begin{array}{c}\text { A. sect. Alternaria } \\
\text { DNA }\end{array}$ & $\begin{array}{c}\text { A. sect. Infectoriae } \\
\text { DNA }\end{array}$ & $\mathrm{AOH}$ & AME & TEN & $\mathrm{TeA}$ \\
\hline cereal species & $\begin{array}{c}\mathrm{F}^{1}=3.50 \\
p=0.03\end{array}$ & $\begin{array}{c}\mathrm{F}=7.48 \\
p=0.001\end{array}$ & $\begin{array}{c}\mathrm{F}=7.25 \\
p=0.0009\end{array}$ & $\mathrm{~ns}^{2}$ & $\begin{array}{l}\mathrm{F}=3.32 \\
p=0.04\end{array}$ & ns \\
\hline $\begin{array}{c}\text { geographic } \\
\text { origin }\end{array}$ & $\begin{array}{l}\mathrm{F}=6.03 \\
p=0.02\end{array}$ & ns & ns & ns & ns & ns \\
\hline crop year & ns & $\begin{array}{c}\mathrm{F}=12.03 \\
p=0.00001\end{array}$ & ns & $\begin{array}{c}F=3.06 \\
p=0.049\end{array}$ & $\begin{array}{c}\mathrm{F}=9.48 \\
p=0.002\end{array}$ & ns \\
\hline
\end{tabular}

${ }^{1} \mathrm{~F}$-value of Fisher test; $p$ —significance level; ${ }^{2}$ ns—-marked not significant values.

The key factors affecting the contamination of grain with A. sect. Alternaria fungi were the cereal species and geographic origin of the samples. At the same time, the incidence of $A$. sect. Infectoriae fungi in grain samples was significantly related to cereal species and weather conditions prevailing in crop years. In the case of mycotoxin contamination of grain, the origin of the samples was not significant, in contrast to the other two factors. The cereal species confidently affected grain contamination with AOH and TEN, and the crop year conditions were important for the accumulation of AME and TEN.

\subsubsection{The Effect of Cereal Crop Species}

The amounts of Alternaria spp. DNA belonging to the two sections differed significantly by cereal grain (Figure 1 ). The barley contained significantly more A. sect. Alternaria DNA $\left(3233 \times 10^{-4} \mathrm{pg} / \mathrm{ng}\right)$ than oat $\left(1781 \times 10^{-4} \mathrm{pg} / \mathrm{ng}\right)$ and wheat $\left(2521 \times 10^{-4} \mathrm{pg} / \mathrm{ng}\right)$. The highest average amount of $A$. sect. Infectoriae DNA was also found in barley $\left(729 \times 10^{-4} \mathrm{pg} / \mathrm{ng}\right)$, which was 1.6 times more than that in wheat $\left(445 \times 10^{-4} \mathrm{pg} / \mathrm{ng}\right)$ and 4.9 times more than that in oat $\left(148 \times 10^{-4} \mathrm{pg} / \mathrm{ng}\right)$.

The comparison of different cereals according to their contamination with Alternaria mycotoxins revealed that the occurrence of all mycotoxins was more frequent in oat grain (Table 5).

Table 5. The occurrence of Alternaria mycotoxins in the grain samples of the different cereals.

\begin{tabular}{ccccc}
\hline \multirow{2}{*}{$\begin{array}{c}\text { Cereals } \\
\text { (No. of Samples) }\end{array}$} & \multicolumn{4}{c}{ The Proportion of Samples Containing Mycotoxin, \% } \\
\cline { 2 - 5 } & AOH & AME & TEN & TeA \\
\hline Barley (49) & 12 & 2 & 88 & 73 \\
Oat (13) & 46 & 31 & 100 & 92 \\
Wheat (116) & 31 & 15 & 90 & 90 \\
\hline
\end{tabular}




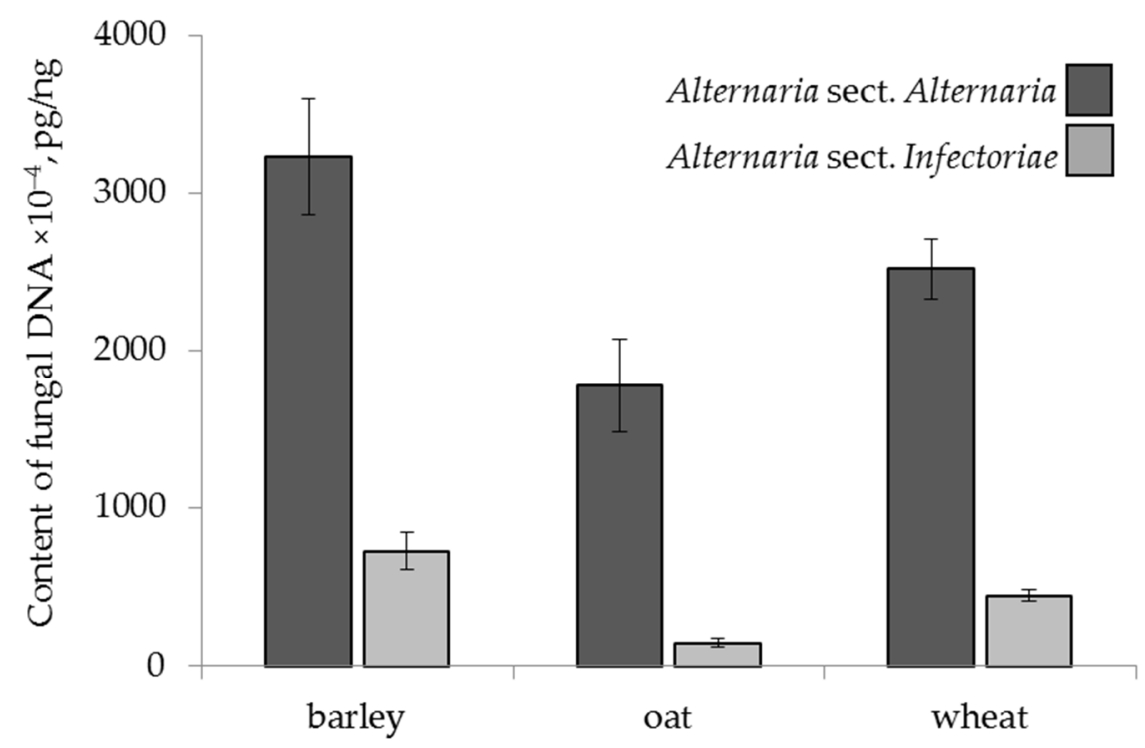

Figure 1. The DNA content of two sections of Alternaria fungi in the grain samples of the different cereals. The bars indicate confidence intervals with a 95\% significance level.

The content of $\mathrm{AOH}$ in oat grain samples was significantly higher $(18 \pm 5 \mu \mathrm{g} / \mathrm{kg})$ than that found in wheat and barley. Barley was less contaminated with $\mathrm{AOH}$ and TEN than wheat (Figure 2). The mycotoxin AME was present only in one barley sample. The content of TEN in barley samples was, on average, lower $(15 \pm 2 \mu \mathrm{g} / \mathrm{kg})$ than that in wheat and similar to that in oat. The difference between the average amounts of AME and TEN in wheat and oat grain samples was not detected. The content of TeA did not differ on average in the grain samples of all three cereals and reached $261 \pm 133 \mu \mathrm{g} / \mathrm{kg}$ for wheat, $120 \pm 20 \mu \mathrm{g} / \mathrm{kg}$ for barley and $309 \pm 112 \mu \mathrm{g} / \mathrm{kg}$ for oat.

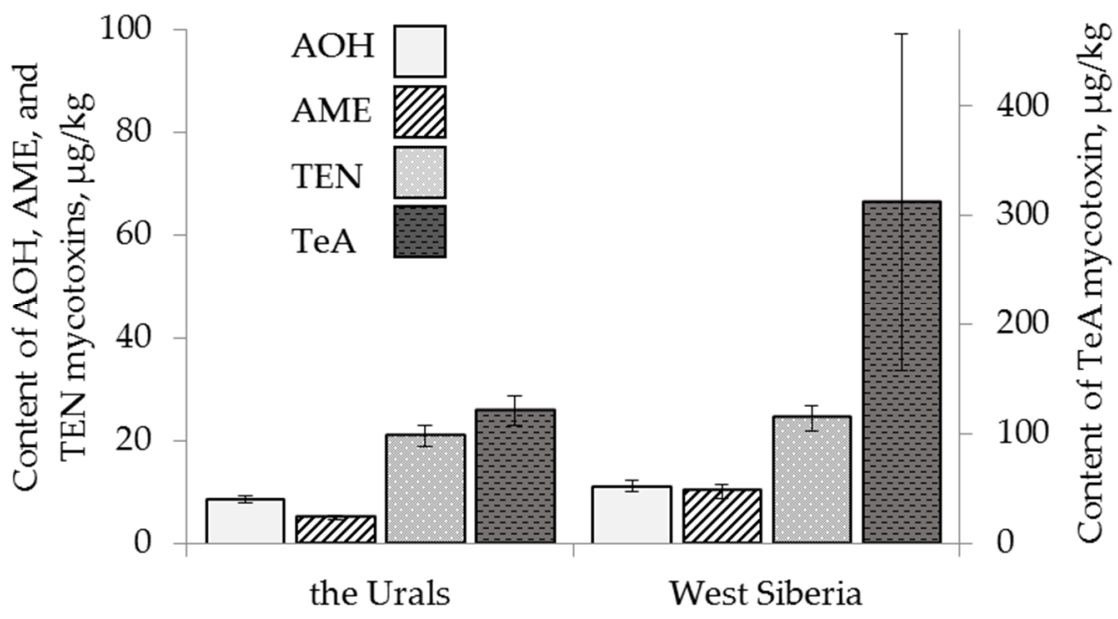

Figure 2. The content of Alternaria mycotoxins in the grain samples of the different cereals. The bars indicate confidence intervals with a 95\% significance level. AOH: alternariol, AME: alternariol monomethyl ether, TEN: tentoxin, TeA: tenuazonic acid.

\subsubsection{The Effect of Geographical Origin}

The amount of A. sect. Alternaria DNA in grain from the Urals averaged (2215 \pm 139$)$ $\times 10^{-4} \mathrm{pg} / \mathrm{ng}$, while in grain from West Siberia, the content of these fungi was significantly higher at $(2989 \pm 262) \times 10^{-4} \mathrm{pg} / \mathrm{ng}$. The amounts of $A$. sect. Infectoriae DNA in grain samples from the Urals and West Siberia were lower, and there was no significant difference between them: $(587 \pm 139) \times 10^{-4}$ and $(440 \pm 90) \times 10^{-4} \mathrm{pg} / \mathrm{ng}$, respectively (Figure 3$)$. 


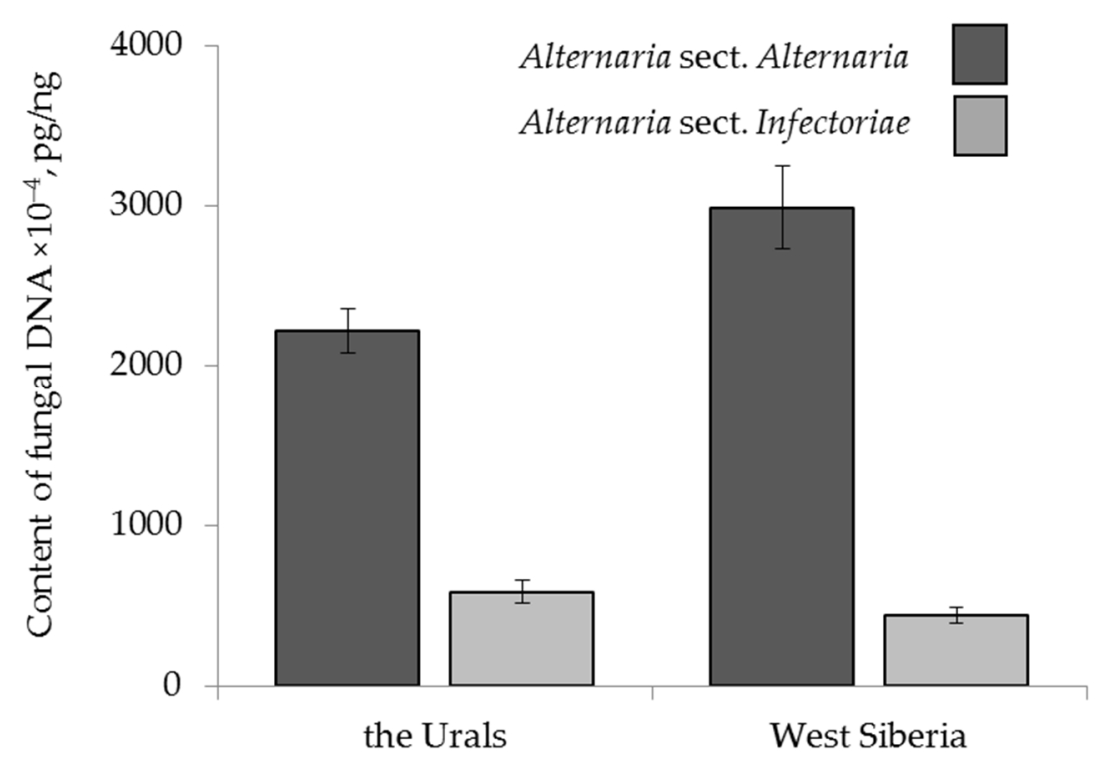

Figure 3. The DNA content of two sections of Alternaria fungi in the grain samples collected from the Urals and West Siberia in 2017-2019. The bars indicate confidence intervals with a 95\% significance level.

Mycotoxins $\mathrm{AOH}$ and $\mathrm{AME}$ were more frequent in grain from the West Siberia region ( $30 \%$ and $15 \%$ of samples, respectively) than in grain from the Urals $(23 \%$ and $9 \%$, respectively). The frequency of occurrence of TEN and TeA in grain from two regions was similar: TEN in $91 \%$ of the samples from the Urals and in $89 \%$ of the samples from West Siberia and $\mathrm{TeA}$ in $85 \%$ of the samples in each region. The contents of AOH, AME and TEN in grain from West Siberia $(11,10$ and $21 \mu \mathrm{g} / \mathrm{kg}$ ), on average, were similar to those in grain from the Urals $(9,5$ and $24 \mu \mathrm{g} / \mathrm{kg})$. At the same time, the TeA content in grain from West Siberia was $312 \pm 154 \mu \mathrm{g} / \mathrm{kg}$, which was 2.6 times higher than that in grain from the Urals $(121 \pm 14 \mu \mathrm{g} / \mathrm{kg})$, but this difference was not significant.

\subsubsection{The Effect of Year}

The years 2017-2019 were characterized by different weather conditions: a gradual decrease in the average summer temperature by $0.5{ }^{\circ} \mathrm{C}$ was noted during this period. In 2018, there was 25-35\% less precipitation than in 2017 and 2019.

The amounts of DNA from the analysed fungi in the grain harvested in these years varied significantly. A substantial decrease in the amount of $A$. sect. Infectoriae DNA in grain, from $789 \times 10^{-4} \mathrm{pg} / \mathrm{ng}$ in 2017 to $252 \times 10^{-4} \mathrm{pg} / \mathrm{ng}$ in 2019 , was observed (Figure 4). A similar trend was also found for the amount of A. sect. Alternaria DNA, from $3021 \times 10^{-4} \mathrm{pg} / \mathrm{ng}$ in 2017 to $2150 \times 10^{-4} \mathrm{pg} / \mathrm{ng}$ in 2019 .

The analysis of weather conditions during the vegetation period of the examined cereals in the three years investigated here revealed that only the average rainfall in July had a significant effect on the contamination of grain with fungi of $A$. sect. Infectoriae $(\mathrm{r}=0.24, p<0.001)$. At the same time, the DNA content of $A$. sect. Alternaria was positively correlated with average temperature $(\mathrm{r}=0.31, p<0.001)$ and rainfall $(\mathrm{r}=0.19, p<0.001)$ in June. In July, the correlations were negative, and the relationships between the average monthly temperature and rainfall and the DNA content of $A$. sect. Alternaria obtained in grain were $\mathrm{r}=-0.19$ at $p=0.01$ and $\mathrm{r}=-0.21$ at $p=0.01$. Rainfall in August also negatively affected grain infection by the fungi $(r=-0.17, p=0.005)$. 


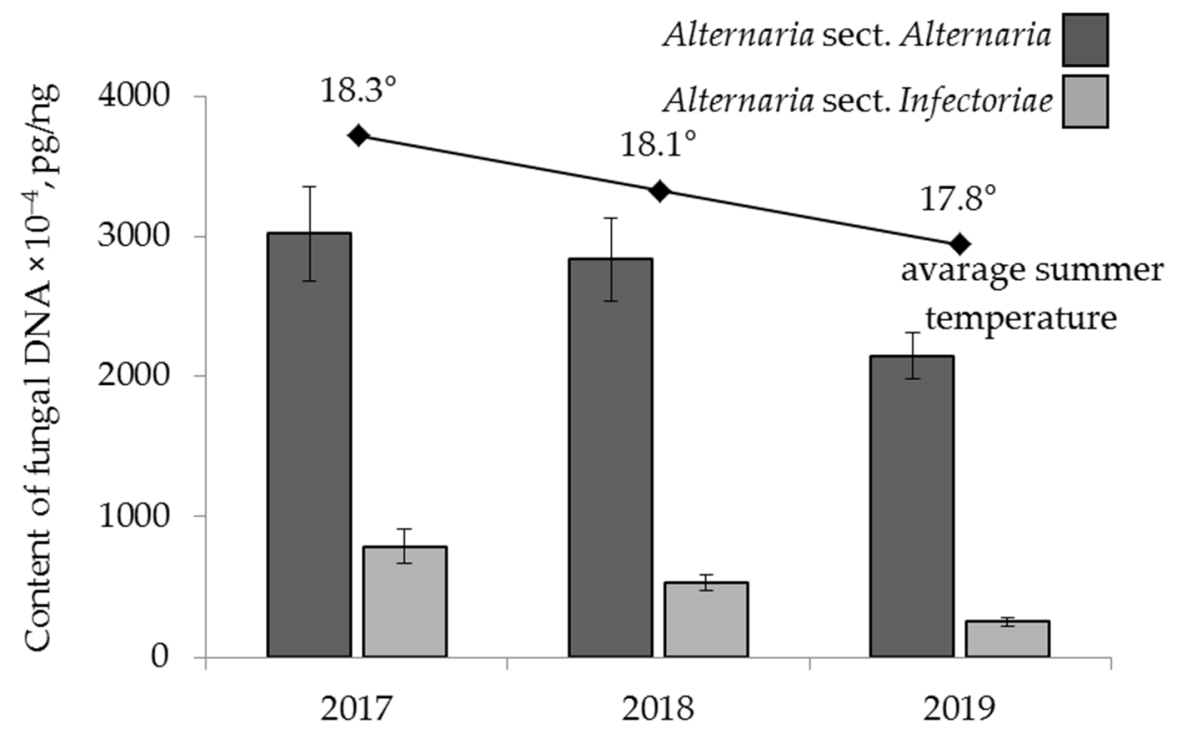

Figure 4. The DNA content of two sections of Alternaria fungi in the grain samples. The bars indicate confidence intervals with a $95 \%$ significance level.

Among the analysed mycotoxins, the content of TEN showed a similar trend, decreasing both in occurrence in grain (from $100 \%$ to $80 \%$ of samples) and in the average content (from $36 \mu \mathrm{g} / \mathrm{kg}$ to $9 \mu \mathrm{g} / \mathrm{kg}$ ) in the period 2017-2019 (Figure 5). The content of TEN had a significant correlation only with the average temperature in June $(r=+0.25, p<0.001)$ and did not depend on climatic factors in other months. The significant correlation between the content of other mycotoxins in the grain and weather conditions during the vegetation period of 2017-2019 was not established.

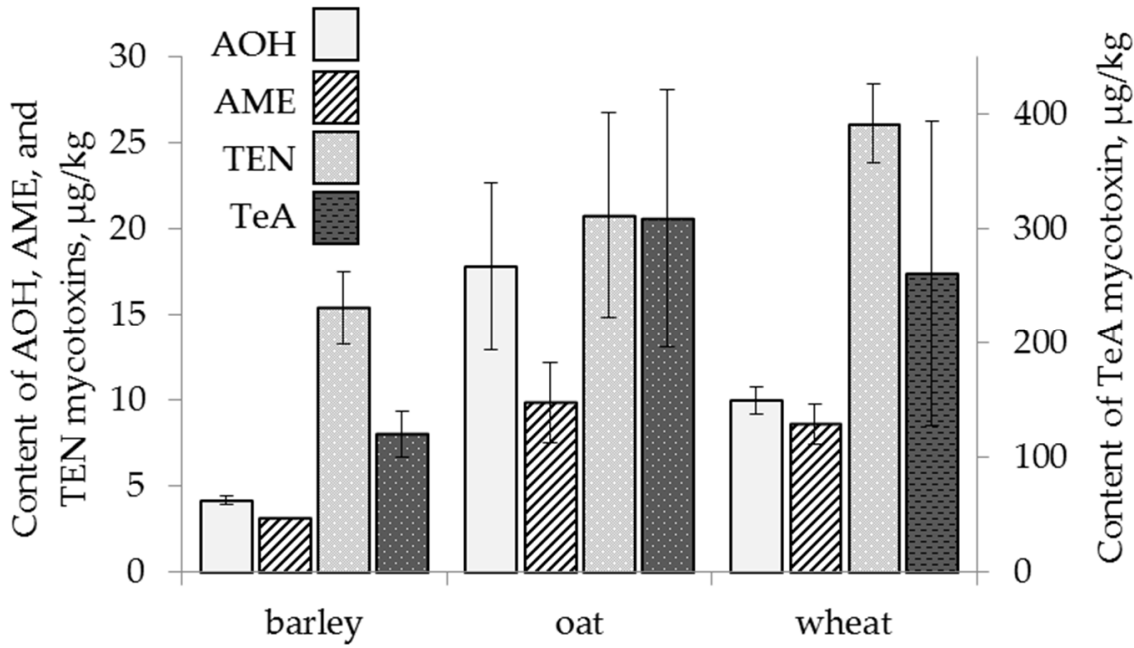

Figure 5. The content of Alternaria mycotoxins in the grain samples. The bars indicate confidence intervals with a 95\% significance level. AOH: alternariol, AME: alternariol monomethyl ether, TEN: tentoxin, TeA: tenuazonic acid.

The lowest occurrence of $\mathrm{AOH}$ and AME in the grain was observed among samples harvested in 2018 ( $22 \%$ and $9 \%$ of samples, respectively), while the highest occurrence of $\mathrm{AOH}$ and $\mathrm{AME}$ in the grain was found in samples from 2017 (39\% and $22 \%$ of samples). Among grain samples harvested in 2019, AOH and AME were detected in $25 \%$ and $11 \%$ of the samples, respectively. The average AME content in the grain harvested in 2018 was $4 \mu \mathrm{g} / \mathrm{kg}$, while in 2019 and 2017, this value was 2.0-2.9 times higher.

The occurrence of TeA in the samples harvested in 2017 and 2019 turned out to be similar (95\% and $98 \%$ of the samples), while in the samples harvested in 2018, it was lower 
(73\%). However, in the samples harvested in 2018, the average TeA content $(409 \mu \mathrm{g} / \mathrm{kg})$ was 3.1-3.8 times higher than that in the samples harvested in 2017 and 2019.

\section{Discussion}

Alternaria spp. are abundantly present in the grain mycobiota in the Urals and West Siberia regions of Russia [14,38] and neighbouring territories such as Kazakhstan [39] and China [34]. Until recently, $A$. sect. Alternaria fungi were thought to be evenly distributed in Russia, while $A$. sect. Infectoriae species were often found in Europe, rarely in the Urals and Siberia, and were absent in the Russian Far East [40]. However, our study demonstrated the significant abundance of $A$. sect. Infectoriae fungi in grain in the Urals and West Siberia regions, which is consistent with the recent results of a mycological analysis of grain grown in these regions [34].

The accurate morphological identification of Alternaria spp. is difficult due to the vagueness of species boundaries [32,41,42]. In this research, for the first time, the use of specific primers for the molecular detection of fungi belonging to two Alternaria sections, Alternaria and Infectoriae, allowed us to establish the contamination of grain with those fungi through DNA content and to comprehensively analyse the occurrence of different Alternaria fungi in cereals. The specificity of primers previously developed for qualitative analysis [43,44] was confirmed during qPCR. Thus, the quantitative detection of Alternaria DNA in grain was carried out at the level of two sections, Alternaria and Infectoriae, whereas earlier, a similar study was focused on the genus level [8]. The difference in Ct of detection is explained by the location of the annealing sites in the genome. The primer set AAF2/AAR3 amplified the fragment of the high-copy ITS region [43]. The primer set AinfF3/AinfR4 was designed based on the sequence of specific DNA fragments obtained by UP-PCR, which is probably a single- or oligo-copy genome locus [44].

DNA of Alternaria fungi of both sections was found in all analysed grain samples. A significant positive correlation between the amounts of A. sect. Alternaria and A. sect. Infectoriae DNA in grain was revealed, which indicates that both groups of species need very similar conditions for their development. The predominance of $A$. sect. Alternaria fungi over A. sect. Infectoriae in the analysed grain samples was observed: the amount of Alternaria spp. DNA from sect. Alternaria was more than 5 times higher than that of $A$. sect. Infectoriae. Notably, $A$. sect. Infectoriae fungi are often characterized by a higher growth rate [45], and these fungi are dominant in wheat, barley and oats grown in Norway [46] and Australia [9]. At the same time, $A$. sect. Alternaria fungi form a denser pigmented mycelium [31] and abundant sporulation [47], which likely provides a competitive advantage in the conditions of the Urals and West Siberia. The prevalence of $A$. sect. Alternaria fungi was also noted in grain from Hebei Province in China [34]. These fungi are widespread in wheat and barley grains in Asia and produce the main Alternaria mycotoxins, such as $\mathrm{AOH}, \mathrm{AME}$, and TeA [34,48]. In our study, a strong positive correlation between the contents of $A$. sect. Alternaria DNA and TeA was revealed, which indicates the key role of these fungi as the main producers of TeA in grain, at least in the observed territory. However, there was no reliable connection between the amount of $A$. sect. Infectoriae DNA and any analysed mycotoxins in grain. The proportion of Alternaria spp. from the sections Alternaria and Infectoriae in the grain mycobiota can vary and largely depends on weather conditions, as well as on the host plant $[10,46]$, which finally determines the contamination of grain with mycotoxins.

Most grain samples were contaminated with at least two Alternaria mycotoxins, and only $3 \%$ of analysed grain samples were free from mycotoxins. Recently, the predominance of Alternaria mycotoxins (mainly TEN) in grain samples from the Urals and Siberia region of Russia has also been shown $[14,36]$. In our study, TeA and TEN were found more often than $\mathrm{AOH}$ and $\mathrm{AME}$ in the grain samples from both regions, which corresponds to previous reports indicating these Alternaria mycotoxins are the most common in grain grown in Asia [22,34]. 
Consistent with previously published data [23,49], the amounts of AOH, AME and TEN were, as a rule, lower than the amounts of TeA in the same grain samples and did not exceed $100 \mu \mathrm{g} / \mathrm{kg}$. The amounts of AOH and AME in the analysed grain reached $53 \mu \mathrm{g} / \mathrm{kg}$ and $56 \mu \mathrm{g} / \mathrm{kg}$, respectively, when, previously, the maximum detected amount of $\mathrm{AOH}$ in Russia was $675 \mu \mathrm{g} / \mathrm{kg}$ in wheat from the North Caucasus region and $397 \mu \mathrm{g} / \mathrm{kg}$ in barley from the Central European region [35]. The authors noted the unequal distribution of abundances of $\mathrm{AOH}$ in grain samples. Half of the data were less than the median value, and the largest amounts of $\mathrm{AOH}$ exceeded the threshold concentrations calculated for the 90th percentile, which indicated the possibility of its abnormally high accumulation.

Only in two grain samples did the amount of TEN exceed $100 \mu \mathrm{g} / \mathrm{kg}$. TeA was detected in significant amounts, more than the recommended benchmark value of $500 \mu \mathrm{g} / \mathrm{kg}$ [29], in eight grain samples. Meanwhile, TeA is an acutely toxic substance with oral LD50 values ranging from 81 to $225 \mathrm{mg} / \mathrm{kg}$ bw for mice [50]. One wheat sample from West Siberia (Altai Krai) contained TeA in an extremely high amount of $15,000 \mu \mathrm{g} / \mathrm{kg}$. To our knowledge, this is the highest recorded natural contamination of wheat grain with this mycotoxin. Previously, the highest amounts of TeA were detected in wheat grain in Argentina $-8814 \mu \mathrm{g} / \mathrm{kg}$ [51], Germany— $4179 \mu \mathrm{g} / \mathrm{kg}$ [52], and China—6432 $\mu \mathrm{g} / \mathrm{kg}$ [53], $3331 \mu \mathrm{g} / \mathrm{kg}$ [22] and $3634 \mu \mathrm{g} / \mathrm{kg}$ [34]. In our study, the grain sample of wheat from Altai Krai that was contaminated by the maximal amount of TeA also contained the maximum quantity of A. sect. Alternaria DNA.

The co-occurrence of $\mathrm{AOH}$ and $\mathrm{AME}$ with $\mathrm{TeA}$ was found in $10 \%$ of the analysed grain samples. This phenomenon was observed repeatedly, and it has been shown that the TeA content was higher than that of other mycotoxins [22,23,26,34,54]. A significant positive correlation between $\mathrm{AOH}$ and $\mathrm{AME}$, which are derivatives of the same chemical precursor dibenzopyrone, and between $\mathrm{AOH}$ and TeA was revealed. Recently, similar statistically significant correlations between different Alternaria toxins were revealed in wheat grain samples and wheat-based products from China [22,55]. The main danger of the co-occurrence of Alternaria mycotoxins is synergistic for additive interactions between these toxic metabolites that may enhance the negative health effects of consumers [55].

In our study, the significant effects of cereal species, geographic origin of samples and weather conditions during the vegetation season on fungal and mycotoxin contamination were established.

According to quantitative analysis of average DNA levels, barley grain was the most heavily contaminated by Alternaria spp., as opposed to oats. The mycological analysis of grain grown in Greece showed a similar result: barley grain was the most heavily infected with Alternaria fungi, in contrast with wheat and oat grain [56].

Very likely, the amount of fungal DNA in grain barely reflects the amounts of corresponding mycotoxins. Over three years, oat grain samples were, on average, the most heavily contaminated with mycotoxins, despite being the least infected. Barley grain was the least contaminated cereal and contained the lowest average amounts of mycotoxins. A similar result was obtained when 76 grain samples from southern Norway were analysed: the occurrence of TEN and TeA in oat grain was significantly higher than that in barley and wheat, although the detected contents of these mycotoxins were low [54]. The analysis of 110 grain samples from Latvia revealed the more significant contamination of oat grain by $\mathrm{AOH}$ and AME compared to rye, winter wheat, and barley [57]. Under laboratory conditions during artificial inoculation, a significant effect of the grain substrate on the accumulated levels of mycotoxin by A. alternata (Fr.) Keissl. strains has also been shown [58].

The prevalence of $\mathrm{AOH}$ and its accumulated amounts, in comparison with $\mathrm{TeA}$ and AME, in barley grain was also revealed, but the authors noted a significant effect of weather conditions on the occurrence of mycotoxins [25].

The abundance of fungi belonging to $A$. sect. Alternaria was significantly higher in grain samples from West Siberia than in grain samples from the Urals. Perhaps this can be explained by the difference in climatic conditions: the summer temperature in West Siberia, 
over a three-year average, was $1.3^{\circ} \mathrm{C}$ higher. The difference between the contamination of grain with fungi of $A$. sect. Infectoriae from the two observed regions was not revealed.

The analysis of weather conditions during different vegetation periods revealed that the DNA content of $A$. sect. Alternaria fungi in grain positively correlated with average temperature and average rainfall in June but had a negative relation in July-August. Warm and humid weather during the periods of wheat flowering, sprouting and heading (late April to June) in Anhui Province in China was favourable to cereal infection by Alternaria fungi [22]. In the case of DNA analysis of $A$. sect. Infectoriae, only the abundance of the average rainfall in July had a significant effect on infection of grain. Among the four mycotoxins, a significant positive correlation with the average temperature in June was revealed only for TEN.

Weather influenced the level and distribution of Alternaria mycotoxin contamination of grain in Argentina when wetter conditions during the wheat-growing season with heavy rainfall in August and December led to high concentrations of mycotoxins [51]. Regardless of climatic conditions, TeA was always present in wheat grain from Serbia, with different frequencies and at different concentrations [59], but in the year with the highest amount of precipitation (up to $170 \%$ increased amount of rainfall compared to long-term annual precipitation data), fungal growth and production of $\mathrm{AOH}$ and $\mathrm{TeA}$ increased and were observed to have the highest values.

Previously, it was revealed that the number of Alternaria spp. conidia in field air and the amount of Alternaria DNA in cereal plant tissue were higher with a lower humidity and a higher temperature [60]. Most likely, the penetration of Alternaria spp. into the grains occurs at the early stages of plant growth in June, which is favoured by high temperature and the absence of competitors. The revealed trends should be compared with the results obtained under other climatic conditions for other cereal crops.

\section{Conclusions}

For the first time, grain contamination with Alternaria fungi was analysed using qPCR at the section level. The ubiquitous presence of Alternaria spp. belonging to sections Alternaria and Infectoriae and their mycotoxins in the grain of wheat, barley and oats in the Urals and West Siberia was demonstrated. The prevalence of DNA of $A$. sect. Alternaria fungi over the DNA of $A$. sect. Infectoriae in the grain samples was revealed.

The $97 \%$ grain samples were contaminated with at least one Alternaria mycotoxin. The new global maximum level of natural contamination of wheat grain with TeA $(15,000 \mu \mathrm{g} / \mathrm{kg})$ was detected. The relationship between grain infection, which was determined as the abundance of fungal DNA, and the content of mycotoxins in certain species of cereal was established. Frequent co-contamination of grain with Alternaria mycotoxins and the revealed extremely high TeA content in wheat grain showed the necessity of further research addressing this problem as well as the development of measures to control grain contamination with Alternaria mycotoxins.

\section{Materials and Methods}

\subsection{Grain Samples and Weather Conditions of Vegetation Seasons in the Analysed Regions}

The sampling was carried out by the specialists of the Russian Agricultural Center in accordance with the standard protocol adopted in Russia. In total, 75 grain samples of cereal crops grown in four locations in the Urals (Chelyabinsk, Kurgan, Tyumen, and Sverdlovsk regions) and 103 grain samples from five locations in West Siberia (Altai Krai, the southern part of Krasnoyarsk Krai, Kemerovo, Novosibirsk, and Omsk regions) in 2017-2019 were analysed. Grain samples were represented by 116 wheat, 49 barley and 13 oat samples.

The available data on climatic conditions in the Urals and West Siberia regions in 2017-2019 are presented in Table 6. 
Table 6. Weather data during the growing season of 2017-2019 in the Urals and West Siberia regions (https://rp5.ru/, accessed on 20 July 2021).

\begin{tabular}{|c|c|c|c|c|c|c|}
\hline Region & Year & Month & $\begin{array}{l}\text { Average Month } \\
\text { Temperature, }{ }^{\circ} \mathrm{C}\end{array}$ & $\begin{array}{l}\text { Average Summer } \\
\text { Temperature, }{ }^{\circ} \mathrm{C}\end{array}$ & Rainfall, mm & $\begin{array}{l}\text { Days with } \\
\text { Precipitation }\end{array}$ \\
\hline \multirow{9}{*}{ the Urals } & \multirow{3}{*}{2017} & June & +16.6 & \multirow{3}{*}{+17.7} & 72 & 19 \\
\hline & & July & +18.5 & & 109 & 19 \\
\hline & & August & +18.0 & & 57 & 13 \\
\hline & \multirow{3}{*}{2018} & June & +15.0 & \multirow{3}{*}{+17.5} & 36 & 19 \\
\hline & & July & +21.0 & & 90 & 13 \\
\hline & & August & +16.5 & & 65 & 19 \\
\hline & \multirow{3}{*}{2019} & June & +15.9 & \multirow{3}{*}{+17.5} & 64 & 18 \\
\hline & & July & +20.3 & & 75 & 14 \\
\hline & & August & +16.4 & & 85 & 18 \\
\hline \multirow{9}{*}{$\begin{array}{l}\text { West } \\
\text { Siberia }\end{array}$} & \multirow{3}{*}{2017} & June & +20.2 & \multirow{3}{*}{+18.9} & 50 & 14 \\
\hline & & July & +19.0 & & 94 & 23 \\
\hline & & August & +17.5 & & 69 & 16 \\
\hline & \multirow{3}{*}{2018} & June & +19.9 & \multirow{3}{*}{+18.6} & 64 & 16 \\
\hline & & July & +18.9 & & 52 & 14 \\
\hline & & August & +17.1 & & 26 & 13 \\
\hline & \multirow{3}{*}{2019} & June & +16.6 & \multirow{3}{*}{+18.1} & 48 & 16 \\
\hline & & July & +19.3 & & 83 & 12 \\
\hline & & August & +18.5 & & 61 & 17 \\
\hline
\end{tabular}

\subsection{Grinding Samples}

From each grain sample $20 \mathrm{~g}$ was taken and then homogenized in a grinding chamber of a batch mill with a tube mill control (IKA, Königswinter, Germany) for extraction of DNA and mycotoxins. The ground cereal flour was stored at $-20{ }^{\circ} \mathrm{C}$ until DNA and mycotoxins were extracted.

\subsection{DNA Extraction and Concentration Measurement}

The extraction of total DNA from $200 \mathrm{mg}$ of flour sample, as well as from the mycelium of Alternaria spp. strains, was performed using the Genomic DNA Purification Kit (Thermo Fisher Scientific, Vilnius, Lithuania) according to the adapted protocol. Total concentrations of DNA were determined using a Qubit 2.0 Fluorometer with a Quant-iT dsDNA HS Assay Kit (Thermo Fisher Scientific, Waltham, MA, USA). The DNA of the fungal strains was diluted to a concentration of $10 \mathrm{ng} / \mu \mathrm{L}$ and used to construct a calibration curve. The DNA isolated from analysed grain samples was aligned to $2-50 \mathrm{ng} / \mu \mathrm{L}$.

\subsection{Detection of Fungal DNA Content in Grain Using qPCR}

The amounts of DNA from Alternaria fungi belonging to sections Alternaria and Infectoriae were determined using SYBR Green qPCR with primers designed for the qualitative detection of Alternaria spp. belonging to the two sections and adapted for the quantitative analysis of their presence in the grain samples (Table 7). The reaction was carried out in a $20 \mu \mathrm{L}$ volume containing $4 \mu \mathrm{L}$ of $5 \times$ qPCRmix-HS SYBR master mix (Evrogen, Moscow, Russia), each primer at $500 \mathrm{nM}$, and $2 \mu \mathrm{L}$ of DNA solution. All qPCR assays were performed using a CFX 96 Real-Time System thermocycler (BioRad, Hercules, CA, USA). Fold differences and standard errors were calculated from the Ct values using the Bio-Rad CFX Manager 1.6 software package. To determine the sensitivity and specificity of the analysis, the DNA of 12 strains stored in the Laboratory of Mycology and Phytopathology of the All-Russian Institute of Plant Protection (St. Petersburg, Russia) were selected. Among the samples were strains of the genus Alternaria of the sections Alternaria, Infectoriae, and Pseudoalternaria, as well as fungi of the genera Bipolaris Shoemaker, Cladosporium Link, Fusarium Link, and Trichothecium Link, common representatives of the cereal grain mycobiota. The 
content of Alternaria spp. DNA in grain samples was presented as the ratio of fungal DNA to total DNA isolated from each sample ( $\mathrm{pg} / \mathrm{ng})$. The quantification value of $5 \times 10^{-4} \mathrm{pg}$ of fungal DNA in one ng of total DNA was established as the threshold of the low limit of DNA in a sample, which can be quantitatively determined with high precision.

Table 7. The primers and the protocols of quantitative PCR used in this study.

\begin{tabular}{cccc}
\hline Target & The Primers & Primer Sequence $\left(5^{\prime} \rightarrow \mathbf{3}^{\prime}\right)$ & Protocol \\
\hline A. sect. & AAF2 & TGCAATCAGCGTCAGTAACAAA & $50^{\circ}$ for $2 \mathrm{~min} ; 95^{\circ}$ for $10 \mathrm{~min} ;\left[95^{\circ}\right.$ for $15 \mathrm{~s} ;$ \\
Alternaria & AAR3 & ATGGATGCTAGACCTTTGCTGAT & $67^{\circ}$ for $60 \mathrm{~s} ; 72^{\circ}$ for $\left.5 \mathrm{~s}\right] \times 40$ \\
\hline $\begin{array}{c}\text { A. sect. } \\
\text { Infectoriae }\end{array}$ & AinfF3 & CTCGATGTCCGCCTCAGTAG & $50^{\circ}$ for $2 \mathrm{~min} ; 95^{\circ}$ for $10 \mathrm{~min} ;\left[95^{\circ}\right.$ for $15 \mathrm{~s} ;$ \\
\hline
\end{tabular}

\subsection{Analysis of Secondary Metabolites of Fungi by HPLC-MS/MS}

The mycotoxins analysis was carried out according to the standard method [61]. Metabolites were extracted from $5 \mathrm{~g}$ of cereal flour by adding $20 \mathrm{~mL}$ of extraction solvent (acetonitrile/water/acetic acid, 79:20:1, $v / v / v$ ) and mixing on a PSU-20 rotary shaker (Biosan, Riga, Latvia) for $90 \mathrm{~min}$. Two independent extractions were prepared for each sample. Then, the extracts were centrifuged for $2 \mathrm{~min}$ at $3000 \mathrm{rpm}$ (Polycom CLn-16, Moscow, Russia). Five hundred microlitres of each extract without any purification was transferred into glass vials, and $500 \mu \mathrm{L}$ of a solution of acetonitrile:water:acetic acid 20:79:1 was added. Then, the vials were sealed and shaken for $30 \mathrm{~s}$ on a Vortex Genius3 (IKA, Germany). For analysis, $5 \mu \mathrm{L}$ of each extract solution was taken by an Agilent autosampler (Agilent Technologies, Germany). Two injections were performed in the LC-MS.

The elution was carried out in binary gradient mode with a flow rate of $1000 \mu \mathrm{L} / \mathrm{min}$. Both mobile phases contained $5 \mathrm{mM}$ ammonium acetate and were composed of methanol/ water/acetic acid 10:89:1 (v/v/v; eluent A) and 97:2:1 (v/v/v; eluent B), respectively. After an initial time of $1.5 \mathrm{~min}$ at $100 \% \mathrm{~A}$, the proportion of B was increased linearly to $50 \%$ within 3 min. Further linear increase of B to $100 \%$ within 12.0 min was followed by a hold time of $5 \mathrm{~min}$ at $100 \% \mathrm{~B}$ and $3.5 \mathrm{~min}$ column re-equilibration at $100 \% \mathrm{~A}$. The injection volume was $5 \mu \mathrm{L}$. ESI-MS/MS was performed in the scheduled multiple reaction monitoring (sMRM) mode negative polarity in two separate chromatographic runs. The target cycle time was $1000 \mathrm{~ms}$, the MS pause time was $3 \mathrm{~ms}$, and the detection window width was 40 and $52 \mathrm{~s}$ in the negative ESI mode.

Detection and quantification of four mycotoxins produced by Alternaria fungi were performed on an AB SCIEX Triple Quad 5500 MS/MS system (Applied Biosystems, Foster City, CA, USA) equipped with a TurboV electrospray ionization (ESI) source and a 1290 series UHPLC system (Agilent Technologies, Waldbronn, Germany). Chromatographic separation was carried out at $25^{\circ} \mathrm{C}$ using a Gemini ${ }^{\circledR} \mathrm{C} 18$ column, $150 \times 4.6 \mathrm{~mm}$ (Phenomenex, Torrance, CA, USA). The contents of four mycotoxins, AOH, AME, TEN, and TeA, produced by Alternaria fungi were determined in the extracts. For the quantitative detection of mycotoxins in grain the matrix-matched calibration techniques using standard solutions of mycotoxins (Romer Labs, Tulln, Austria) were applied. The parameters of the HPLC-MS/MS method for the analysed mycotoxins are presented in Table 8.

Table 8. Parameters of HPLC-MS/MS method.

\begin{tabular}{|c|c|c|c|c|c|c|}
\hline \multirow{2}{*}{ Analyte } & \multirow{2}{*}{$\begin{array}{l}\text { Retention } \\
\text { Time, min }\end{array}$} & \multicolumn{5}{|c|}{ MS/MS Parameters } \\
\hline & & $m / z \mathrm{Q} 1$ & $m / z \mathrm{Q}^{1}$ & $\mathrm{DP}(\mathrm{V})^{2}$ & $\mathrm{CE}(\mathrm{V})^{3}$ & CXP (V) ${ }^{4}$ \\
\hline Alternariol $(\mathrm{AOH})$ & 9.67 & 257.0 & $213.0 / 215.0$ & -100 & $-34 /-36$ & $-11 /-11$ \\
\hline Alternariolmethylether (AME) & 11.40 & 271.0 & $256.0 / 227.0$ & -95 & $-32 /-50$ & $-13 /-9$ \\
\hline Tentoxin (TEN) & 8.84 & 413.3 & $141.0 / 271.1$ & -105 & $-30 /-24$ & $-11 /-24$ \\
\hline Tenuazonic acid (TeA) & 8.04 & 196.1 & $139.0 / 112.1$ & -120 & $-28 /-28$ & $-7 /-7$ \\
\hline
\end{tabular}

${ }^{1}$ quantifier/qualifier specific product ions; ${ }^{2}$ declustring potential; ${ }^{3}$ collision energy; ${ }^{4}$ cell exit potential. 
The limit of detection (LOD) for the analysed mycotoxins was established by 20 measurements of each pure matrix and calculation of the average value. The limit of quantification (LOQ) for the analysed mycotoxins was determined by adding each analysed mycotoxin to a pure matrix. When the $\mathrm{S} / \mathrm{N}$ (signal to noise) value of 20 parallel measurements was above five and the reproducibility was above $80 \%$, the LOQ for each matrix was established. The LOD and LOQ for the analysed mycotoxins are presented in Table 9.

Table 9. Precision, limits of detection (LODs), and limits of quantification (LOQ) for the analysed mycotoxins in cereal matrix.

\begin{tabular}{cccc}
\hline Analyte & Precision $( \pm), \%$ & LOD, $\boldsymbol{\mu g} / \mathbf{k g}$ & LOQ, $\boldsymbol{\mu g} / \mathbf{k g}$ \\
\hline Alternariol (AOH) & $10-21$ & & \\
wheat & & 0.79 & 2.39 \\
barley & & 0.82 & 2.46 \\
oat & & 0.82 & 2.60 \\
\hline Alternariolmethylether (AME) & $7-23$ & & \\
wheat & & 0.69 & 2.15 \\
barley & & 0.70 & 2.15 \\
oat & & 0.82 & 2.67 \\
\hline Tentoxin (TEN) & $8-11$ & & \\
wheat & & 0.79 & 2.00 \\
barley & 0.82 & 2.15 \\
oat & & 0.82 & 2.22 \\
\hline Tenuazonic acid (TeA) & $13-21$ & & \\
wheat & & 6.3 & 14.80 \\
barley & & 3.40 & 9.00 \\
oat & & 18.44 & 51.25 \\
\hline
\end{tabular}

\subsection{Statistical Analysis}

Microsoft Excel 2010 was used to calculate the average values and the confidence intervals at a significance level of $p<0.05$. The analysis of data variance and the correlation analysis of quantitative traits expressed by the Pearson coefficient $(r)$ at a significance level of $p<0.05$ were carried out with the STATISTICA 10.0 program.

Author Contributions: Data curation, O.P.G. and A.S.O.; Formal analysis, A.S.O. and O.P.G.; Investigation, A.S.O., O.P.G., T.Y.G. and N.N.G.; Methodology, T.Y.G. and A.S.O.; Project administration, P.B.G.; Supervision, T.Y.G.; Validation, T.Y.G., O.P.G. and A.S.O.; Visualization, A.S.O. and O.P.G.; Writing—original draft, A.S.O. and O.P.G.; Writing—review \& editing, T.Y.G. and P.B.G. All authors have read and agreed to the published version of the manuscript.

Funding: The study was supported by the Russian Science Foundation (project No. 19-76-30005).

Institutional Review Board Statement: Not applicable.

Informed Consent Statement: Not applicable.

Data Availability Statement: Data is contained within the article.

Acknowledgments: We are grateful to the managers of the Russian Branch of Syngenta and Bayer Crop Science for their help with the grain sample collection.

Conflicts of Interest: The authors declare no conflict of interest. The funders had no role in the design of the study; in the collection, analyses, and interpretation of data; in the writing of the manuscript; or in the decision to publish the results. 


\section{References}

1. Ostry, V. Alternaria mycotoxins: An overview of chemical characterization, producers, toxicity, analysis and occurrence in foodstuffs. World Mycotoxin J. 2008, 1, 175-188. [CrossRef]

2. Thomma, B.P.H.J. Alternaria spp.: From general saprophyte to specific parasite. Mol. Plant. Pathol. 2003, 4, 225-236. [CrossRef] [PubMed]

3. Polizzotto, R.; Andersen, B.; Martini, M.; Grisan, S.; Assante, G.; Musetti, R. A polyphasic approach for the characterization of endophytic Alternaria strains isolated from grapevines. J. Microbiol. Methods 2012, 88, 162-171. [CrossRef] [PubMed]

4. Noor, A.; Nava, A.; Cooke, P.; Cook, D.; Creamer, R. Evidence of non-pathogenic relationship of Alternaria section Undifilum endophytes within three host locoweed plants species. Botany 2018, 96, 187-200. [CrossRef]

5. Mamgain, A.; Roychowdhury, R.; Tah, J. Alternaria pathogenicity and its strategic controls. Res. J. Biol. 2013, 1, 1-9.

6. Patriarca, A. Alternaria in food products. Curr. Opin. Food Sci. 2016, 11, 1-9. [CrossRef]

7. Escrivá, L.; Oueslati, S.; Font, G.; Manyes, L. Alternaria mycotoxins in food and feed: An overview. J. Food Qual. 2017, 2017, 1569748. [CrossRef]

8. Kulik, T.; Treder, K.; Załuski, D. Quantification of Alternaria, Cladosporium, Fusarium and Penicillium verrucosum in conventional and organic grains by qPCR. J. Phytopathol. 2015, 163, 522-528. [CrossRef]

9. Barkat, E.; Hardy, G.; Ren, Y.; Calver, M.; Bayliss, K. Fungal contaminants of stored wheat vary between Australian states. Australas. Plant. Pathol. 2016, 45, 621-628. [CrossRef]

10. Gannibal, P.B. Factors affecting Alternaria appearance in grains in European Russia. Sel'skokhozyaistvennaya Biol. 2018, 53, 605-615. [CrossRef]

11. Gashgari, R.; Ameen, F.; Al-Homaidi, E.; Gherbawy, Y.; Al Nadhari, S.; Vijayan, V. Mycotoxigenic fungi contaminating wheat; toxicity of different Alternaria compacta strains. Saudi J. Biol. Sci. 2019, 26, 210-215. [CrossRef] [PubMed]

12. Somma, S.; Amatulli, M.T.; Masiello, M.; Moretti, A.; Logrieco, A.F. Alternaria species associated to wheat black point identified through a multilocus sequence approach. Int. J. Food Microbiol. 2019, 293, 34-43. [CrossRef] [PubMed]

13. Puvača, N.; Bursic, V.; Gorica, V.; Budakov, D.; Petrovic, A.; Merkuri, J.; Avantaggiato, G.; Cara, M. Ascomycete fungi (Alternaria spp.) characterization as major feed grains pathogens. J. Agron. Technol. Eng. Manag. 2020, 3, 499-505.

14. Orina, A.S.; Gavrilova, O.P.; Gagkaeva, T.Y.; Gannibal, P.B. Micromycetes Alternaria spp. and Bipolaris sorokiniana and mycotoxins in the grain from the Ural region. Mikol. Fitopatol. 2020, 54, 365-377. (In Russian) [CrossRef]

15. Kwaśna, H.; Kosiak, B. Lewia avenicola sp. nov. and its Alternaria anamorph from oat grain, with a key to the species of Lewia. Mycol. Res. 2003, 107, 371-376. [CrossRef]

16. Kwaśna, H.; Ward, E.; Kosiak, B. Lewia hordeicola sp. nov. from barley grain. Mycologia 2006, 98, 662-668. [CrossRef]

17. Poursafar, A.; Ghosta, Y.; Orina, A.S.; Gannibal, P.B.; Javan-Nikkhah, M.; Lawrence, D.P. Taxonomic study on Alternaria sections Infectoriae and Pseudoalternaria associated with black (sooty) head mold of wheat and barley in Iran. Mycol. Prog. 2018, 17, 343-356. [CrossRef]

18. Kumar, A.; Karre, S.; Dhokane, D.; Kage, U.; Hukkeri, S.; Kushalappa, A.C. Real-time quantitative PCR based method for the quantification of fungal biomass to discriminate quantitative resistance in barley and wheat genotypes to Fusarium head blight. $J$. Cereal Sci. 2015, 64, 16-22. [CrossRef]

19. Kulik, T.; Bilska, K.; Żelechowski, M. Promising perspectives for detection, identification, and quantification of plant pathogenic fungi and oomycetes through targeting mitochondrial DNA. Int. J. Mol. Sci. 2020, 21, 2645. [CrossRef]

20. Alexander, J.; Benford, D.; Boobis, A.; Ceccatelli, S.; Cottrill, B.; Cravedi, J.-P.; Di Domenico, A.; Doerge, D.; Dogliotti, E.; Edler, L.; et al. Scientific opinion on the risks for animal and public health related to the presence of Alternaria toxins in feed and food. EFSA J. 2011, 9, 2407-2504. [CrossRef]

21. Arcella, D.; Eskola, M.; Gómez Ruiz, J.A. Dietary exposure assessment to Alternaria toxins in the European population. EFSA J. 2016, 14, 4654. [CrossRef]

22. Xu, W.; Han, X.; Li, F.; Zhang, L. Natural occurrence of Alternaria toxins in the 2015 wheat from Anhui province, China. Toxins 2016, 8, 308. [CrossRef]

23. Fraeyman, S.; Croubels, S.; Devreese, M.; Antonissen, G. Emerging Fusarium and Alternaria mycotoxins: Occurrence, toxicity and toxicokinetics. Toxins 2017, 9, 228. [CrossRef]

24. Topi, D.; Tavcar-Kalcher, G.; Pavšič-Vrtač, K.; Babič, J.; Jakovac-Strajn, B. Alternaria mycotoxins in grains from Albania: Alternariol, alternariol monomethyl ether, tenuazonic acid and tentoxin. World Mycotoxin J. 2018, 12, 1-12. [CrossRef]

25. Castañares, E.; Pavicich, M.; Dinolfo, M.; Moreyra, F.; Stenglein, S.; Patriarca, A. Natural occurrence of Alternaria mycotoxins in malting barley grains in the main producing region of Argentina. J. Sci. Food Agri. 2020, 100, 1004-1011. [CrossRef]

26. Babič, J.; Tavčar-Kalcher, G.; Celar, F.A.; Kos, K.; Knific, T.; Jakovac-Strajn, B. Occurrence of Alternaria and other toxins in cereal grains intended for animal feeding collected in Slovenia: A three-year study. Toxins 2021, 13, 304. [CrossRef] [PubMed]

27. Lou, J.; Fu, L.; Peng, Y.; Zhou, L. Metabolites from Alternaria fungi and their bioactivities. Molecules 2013, 18, 5891-5935. [CrossRef] [PubMed]

28. Rychlik, M.; Lepper, H.; Weidner, C.; Asam, S. Risk Evaluation of the Alternaria mycotoxin tenuazonic acid in foods for adults and infants and subsequent risk management. Food Control 2016, 68, 181-185. [CrossRef] 
29. Food Chemistry Institute of the Association of the German Confectionery Industry. Alternaria Toxins: Occurrence, Toxicity, Analytical Methods, Maximum Levels. 2020. Available online: https:/ /www.lci-koeln.de/deutsch/veroeffentlichungen/lcifocus/alternaria-toxins-occurrence-toxicity-analytical-methods-maximum-levels (accessed on 17 August 2021).

30. Tralamazza, S.M.; Piacentini, K.C.; Iwase, C.H.T.; de Oliveira Rocha, L. Toxigenic Alternaria species: Impact in cereals worldwide. Curr. Opin. Food Sci. 2018, 23, 57. [CrossRef]

31. Andersen, B.; Krøger, E.; Roberts, R.G. Chemical and morphological segregation of Alternaria arborescens, A. infectoria and A. tenuissima species-groups. Mycol. Res. 2002, 106, 170-182. [CrossRef]

32. Zwickel, T.; Kahl, S.M.; Rychlik, M.; Müller, M.E.H. Chemotaxonomy of mycotoxigenic small-spored Alternaria fungi-Do multitoxin mixtures act as an indicator for species differentiation? Front. Microbiol. 2018, 9, 1368. [CrossRef]

33. Masiello, M.; Somma, S.; Susca, A.; Ghionna, V.; Logrieco, A.F.; Franzoni, M.; Ravaglia, S.; Meca, G.; Moretti, A. Molecular identification and mycotoxin production by Alternaria species occurring on durum wheat, showing black point symptoms. Toxins 2020, 12, 275. [CrossRef] [PubMed]

34. Jiang, D.; Wei, D.; Li, H.; Wang, L.; Jiang, N.; Li, Y.; Wang, M. Natural occurrence of Alternaria mycotoxins in wheat and potential of reducing associated risks using magnolol. J. Sci. Food Agric. 2021, 101, 3071-3077. [CrossRef] [PubMed]

35. Kononenko, G.P.; Burkin, A.A.; Zotova, E.V. Mycotoxilogical monitoring. Part 2. Wheat, barley, oat and maize grain. Vet. Segodnya 2020, 2, 139-145. [CrossRef]

36. Kiseleva, M.G.; Sedova, I.B.; Chalyy, Z.A.; Zakharova, L.P.; Aristarkhova, T.V.; Tutelyan, V.A. Multi-mycotoxin screening of food grain produced in Russia in 2018. Sel'skokhozyaistvennaya Biol. 2021, 56, 559-577. [CrossRef]

37. Federal State Statistics Service. Bulletins on the State of Agriculture (Electronic Versions). Available online: https:/ /www.gks.ru/ compendium/document/13277 (accessed on 17 August 2021). (In Russian)

38. Toropova, E.Y.; Kirichenko, A.A.; Kazakova, O.A.; Porsev, I.N. Alternaria disease of grain of spring wheat and barley in Western Siberia and Eastern Trans-Urals. Zashchita I Karantin Rasteniy 2015, 1, 20-22. (In Russian)

39. Turzhanova, A.; Khapilina, O.N.; Tumenbayeva, A.; Shevtsov, V.; Raiser, O.; Kalendar, R. Genetic diversity of Alternaria species associated with black point in wheat grains. Peer J. 2020, 5, e9097. [CrossRef]

40. Gannibal, P.B. Alternaria disease of grain-Modern view of the problem. Zashchita I Karantin Rasteniy 2014, 6, 11-15. (In Russian)

41. Woudenberg, J.H.C.; Groenewald, J.Z.; Binder, M.; Crous, P. Alternaria redefined. Stud. Mycol. 2013, 75, 171-212. [CrossRef]

42. Woudenberg, J.H.; Seidl, M.F.; Groenewald, J.Z.; de Vries, M.; Stielow, J.B.; Thomma, B.P.; Crous, P.W. Alternaria section Alternaria: Species, formae speciales or pathotypes? Stud. Mycol. 2015, 82, 1-21. [CrossRef] [PubMed]

43. Konstantinova, P.; Bonants, P.J.M.; van Gent-Pelzer, M.P.E.; van der Zouwen, P.; van den Bulk, R. Development of specific primers for detection and identification of Alternaria spp. in carrot material by PCR and comparison with blotter and plating assays. Mycol. Res. 2002, 106, 23-33. [CrossRef]

44. Gannibal, P.B.; Yli-Mattila, T. Morphological and UP-PCR analyses and design of a PCR assay for differentiation of Alternaria infectoria species-group. Mikol. I Fitopatol. 2007, 41, 313-322.

45. Andersen, B.; Thrane, U. Differentiation of Alternaria infectoria and Alternaria alternata based on morphology, metabolite profiles, and cultural characteristics. Can. J. Microbiol. 1996, 42, 685-689. [CrossRef]

46. Kosiak, B.; Torp, M.; Skjerve, E.; Andersen, B. Alternaria and Fusarium in Norwegian grains of reduced quality-A matched pair sample study. Int. J. Food Microbiol. 2004, 93, 51-62. [CrossRef]

47. Lawrence, D.P.; Gannibal, P.B.; Peever, T.L.; Pryor, B.M. The sections of Alternaria: Formalizing species-group concepts. Mycologia 2013, 105, 530-546. [CrossRef]

48. Nguyen, T.T.T.; Kim, J.; Jeon, S.J.; Lee, C.W.; Magan, N.; Lee, H.B. Mycotoxin production of Alternaria strains isolated from Korean barley grains determined by LC-MS/MS. Int. J. Food Microbiol. 2018, 268, 44-52. [CrossRef] [PubMed]

49. Scott, P.M.; Zhao, W.; Feng, S.; Lau, B.P. Alternaria toxins aternariol and alternariol monomethyl ether in grain foods in Canada. Mycotoxin Res. 2012, 28, 261-266. [CrossRef] [PubMed]

50. Crudo, F.; Varga, E.; Aichinger, G.; Galaverna, G.; Marko, D.; Dall'Asta, C.; Dellafiora, L. Co-occurrence and combinatory effects of Alternaria mycotoxins and other xenobiotics of food origin: Current scenario and future perspectives. Toxins 2019, 11, 640. [CrossRef] [PubMed]

51. Azcarate, M.P.; Patriarca, A.; Terminiello, L.; Fernández, P.V. Alternaria toxins in wheat during the 2004 to 2005 Argentinean harvest. J. Food Prot. 2008, 71, 1262-1265. [CrossRef] [PubMed]

52. Müller, M.E.; Korn, U. Alternaria mycotoxins in wheat-A 10 years survey in the northeast of Germany. Food Control 2013, 34, 191-197. [CrossRef]

53. Li, F.; Yoshizawa, T. Alternaria mycotoxins in weathered wheat from China. J. Agric. Food Chem. 2000, 48, 2920-2924. [CrossRef] [PubMed]

54. Uhlig, S.; Eriksen, G.S.; Hofgaard, I.S.; Krska, R.; Beltrán, E.; Sulyok, M. Faces of a changing climate: Semi-quantitative multi-mycotoxin analysis of grain grown in exceptional climatic conditions in Norway. Toxins 2013, 5, 1682-1697. [CrossRef] [PubMed]

55. Zhao, K.; Shao, B.; Yang, D.; Li, F.; Zhu, J. Natural occurrence of Alternaria toxins in wheat based products and their dietary exposure in China. PLoS ONE 2015, 10, e0132019. [CrossRef] [PubMed]

56. Logrieco, A.; Bottalico, A.; Solfrizzo, M.; Mule, G. Incidence of Alternaria species in grains from Mediterranean countries and their ability to produce mycotoxins. Mycologia 1990, 82, 501-505. [CrossRef] 
57. Reinholds, I.; Jansons, M.; Fedorenko, D.; Pugajeva, I.; Zute, S.; Bartkiene, E.; Bartkevics, V. Mycotoxins in cereals and pulses harvested in Latvia by nanoLC-Orbitrap MS. Food Addit. Contam. Part B 2021, 14, 115-123. [CrossRef]

58. Zwickel, T.; Kahl, S.M.; Klaffke, H.; Rychlik, M.; Müller, M.E. Spotlight on the underdogs-An analysis of underrepresented Alternaria mycotoxins formed depending on varying substrate, time and temperature conditions. Toxins 2016, 8, 344. [CrossRef]

59. Janić Hajnal, E.; Orčić, D.; Torbica, A.; Kos, J.; Mastilović, J.; Škrinjar, M. Alternaria toxins in wheat from the autonomous province of Vojvodina, Serbia: A preliminary survey. Food Addit. Contam. Part A 2015, 32, 361-370. [CrossRef]

60. Schiro, G.; Verch, G.; Grimm, V.; Müller, M.E.H. Alternaria and Fusarium fungi: Differences in distribution and spore deposition in a topographically heterogeneous wheat field. J. Fungi 2018, 4, 63. [CrossRef]

61. Malachová, A.; Sulyok, M.; Beltrán, E.; Berthiller, F.; Krska, R. Optimization and validation of a quantitative liquid chromatography-tandem mass spectrometric method covering 295 bacterial and fungal metabolites including all regulated mycotoxins in four model food matrices. J. Chromatogr. A 2014, 1362, 145-156. [CrossRef] 